\title{
Islamic Pharmacy in the Mamlūk and Mongol Realms: Theory and Practice
}

\author{
Leigh Chipman
}

\begin{abstract}
This article will discuss aspects of pharmacy in the thirteenth and fourteenth centuries $\mathrm{CE}$, when the central Islamic lands - which also form a central part of the Silk Road between China and Europe-were dominated by the Mamlūk Empire in Egypt and Syria, and the Mongol Îl-khāns in Iran. Exchanges of practical and theoretical knowledge occurred across the hostile frontier, but it remains to be seen to what extent this affected the practice of community pharmacists in the Islamic world, let alone the theory used by doctors learned in the Arabic pharmacological tradition. As I have only very recently begun to study the Mongol side of things in greater depth, this article will be weighted towards the Mamlūks, and I will point out areas that require further research before any definite conclusion can be reached. I will begin by discussing the state of pharmacy in Mamlūk Egypt, continue to say a few words about the developments in pharmacology caused by the establishment of the Mongol Empire, and finally, discuss the status of pharmacists in hospitals under the Mongols and Mamlüks.
\end{abstract}

\section{Keywords}

Mamluks, Mongols, Islamic medicine, history of pharmacy, medieval medicine, pharmacology, hospitals

Pharmacy in the thirteenth and fourteenth centuries remained, in the words of one of its foremost practitioners, 'a tool for the craft of medicine' (äla li-sinä at al-tibb). ${ }^{1}$ This being the case, the pharmacists themselves only rarely composed books. An unusual instance of a pharmacist-author is Abū 'l-Munā al-Kühin al-'Ațtāin, whom I have just quoted. He wrote his manual for the management of the pharmacy, Minhäj al-dukkän ('How to run a pharmacy'), in Cairo in 1260. The 25 chapters of this manual provide us with a snapshot of pharmacy and pharmacology in an era of change.

Al-Kühīn al-'Ațtār stands within a long tradition of pharmacopoeias, whose format had its origin in Galen's De Compositione medicamentorum. A typical recipe would be composed of the following elements, not necessarily always in

\footnotetext{
I al-Aț̣ār, 1992 (hereafter $M D$ ), p. 9.
} 
this order: the heading or title of the drug; its indications; the ingredients and their quantities; the manner of preparation; recommended dosage or application. Often, the expression mujarrab (tried) or näfi' (effective, beneficial) will appear at the end of the recipe, sometimes together with the pious hope of in shäa alläh ta'älà (if exalted God so wills). As can be readily seen, the emphasis is on the practical, on therapeutic efficacy, rather than on theory.

Unlike most works in this genre, the structure of Minhäj al-dukkän is that of a mini-encyclopaedia. True to his aim of providing pharmacists with all the knowledge they need, al-Kühin al-Ațtār combined the simple formulary (chapters 2-19) with the relevant sections of encyclopaedias aimed at physicians, such as chapters dealing with weights and measures, glossaries of drug names, and how to verify the authenticity or quality of raw materials. ${ }^{2}$ Most of these additions were placed after the pharmacopoeia proper (chapters 20-25), but like the encyclopaedias which begin by defining the character and qualities desirable in a physician, Minhäj al-dukkän begins with a chapter on the qualities and character of the aspiring pharmacist: he should be honest, Godfearing and knowledgeable in his profession. With this exception, all the material in Minhäj al-dukkän relates to practical rather than theoretical knowledge. Abū al-Munā al-Kūhīn al-'Ațțār provides his readers with instruction in personal and professional ethics (chapters one and twenty-three), practical rules for the handling of materia medica in the form of lists of substitute drugs (chapter 20), synonyms of drug names (chapter 21) and a glossary of weights and measures (chapter 22), and, like any father addressing his son-for such is the persona he assumes-all manner of good advice. ${ }^{3}$

Medical encyclopaedias almost invariably begin with an exposition of the elements, the humours and other basic scientific concepts before moving on to medicine proper. ${ }^{4}$ In contrast, al-Kūhin al-'Attār finishes his first chapter on ethics and plunges straight into the preparation of syrups, not stopping to explain the meaning of amräd balghamiyya, phlegmatic illnesses, for example. It is possible that there is no theoretical section because Minhäj al-dukkän is very much a cookbook: ${ }^{5}$ al-Kūhin al-Ațțār provides recipes to be followed.

2 Examples of medical encyclopaedias are: al-Rāzì, Kitäb al-bạwì fí 'l-țibb; Ibn Sīnā, al-Qãnūn fi' 'l-tibb,; al-Majūsī, Kitäb al-Malaki. See bibiliography for details.

${ }^{3}$ For example, to treat his shop and goods as a learned man treats his books-that is, to check them regularly, and know what is there $(M D$, p. 268).

${ }^{4}$ See, e.g., Ibn Sīnā 1999, first book (vol. 1, pp. 11-102); al-Majūsī, 1294/1877, vol. 1, esp. pp. 15-48; ; Ibn Jumay', first maqäla, fols. 1a-30a; al-Antaki 1998, pp. 23-45.

s Cookbooks themselves, of course, also contain medical material, or what David Waines refers to as 'home remedies' (Waines 1995). For a study of the fine line between cookbooks and materia medica in the Chinese tradition, see Lo and Barrett 2005. 
Theory is not necessary for his purpose, which is to provide remedies, the why and how are unimportant, so long as they are effective.

Syrups are the favoured pharmaceutical form in Minhajj al-dukkän. It is not entirely clear why this should be so, apart from the obvious fact that syrups are the most palatable form of medicine and perhaps therefore in greatest demand. Chapter two, which is devoted to syrups, takes up 40 pages of the 1992 edition, some 13 per cent of the printed text, and considerably more than any other chapter. Moreover, al-Kühīn al-'Ațtār states in his introduction that pharmacy is currently known as 'the craft of perfume and syrups' (sinä'at al'itr wa-' $l$-sharäb $)^{6}$-it is understandable that the basics of preparing these should be set out in great detail. Perfumes and syrups form areas of overlap between the medicinal and the culinary traditions, and indeed, in a Mamlükperiod cookbook, the Kanz al-fawä'id fi tanwi' al-mawä'id ('The treasure of valuable knowledge in the classification of foodstuffs'), ${ }^{7}$ the discussion of how best to handle sugar syrup is almost identical — word for word - to that appearing in Minhäj al-dukkän, reinforcing the conceptualisation of Minhäj aldukkain as a cookbook. Indeed, the medical tradition itself regarded foods and drugs as being part of a continuum, as shown by the many books treating simple drugs bearing the title Kitäb al-aghdhiya wa-'l-adwiya, 'the book of foodstuffs and drugs'.

This attitude of al-Kūhīn al-'Aț̣ār, privileging therapy over theory, appears in the Mongol Empire as well as in the Mamlük Sultanate. In his recent book Culture and Conquest in Mongol Eurasia, ${ }^{8}$ Thomas Allsen makes an impressive case for the thirteenth century being a period of great intellectual ferment and of extensive cultural exchange between China and Iran, and their hinterlands. This exchange did not take place merely at the level of court culture, but also involved the transplanting of technologies and agricultural practices from East to West Asia and vice versa, brought by officials, troops and even peasant communities from one end to another of the Mongol Empire.' In the field of medicine, it seems that physicians were reluctant to abandon the theories they knew, but were happy to accept new therapeutic techniques, and particularly new drugs. ${ }^{10}$ The Nestorian and Muslim physicians of Iran and elsewhere in the Islamic world remained faithful to Galenic humouralism, while Chinese

${ }^{6} M D$, p. 10.

7 Marín and Waines (eds) 1993. As noted by the editors, 'A second feature of interest in the Kanz is the frequency of health references attached as comments to the recipes' (p. 6, English section).

${ }^{8}$ Allsen 2001.

9 Allsen 2001, p. 140.

${ }^{10}$ Allsen 2001, p. 158. 
doctors continued to analyse ill-health in terms of yin-yang and the Five Phases or Agencies. It is true that this analysis changed and developed in the course of the Yuan period, with superficial similarities to the Galenic degrees in drugs, but the basis of the various classifications remained the Chinese tradition. ${ }^{11}$ Similarly, both Islamic and Chinese systems made great use of the pulse as a diagnostic tool, but the theory and practice of pulse-taking differed greatly. ${ }^{12}$

The pharmacists, however, unconcerned with theory, adopted and rediscovered exotic materia medica that was useful. Indeed, from the time of Chinggis Qan the Mongols had taken an interest in the pharmacology of the cultures that they conquered. While Chinese rhubarb, cubebs and white pepper were already an integral part of Persian pharmacology by the tenth and eleventh centuries, it was during the era of Mongol domination that their reputation was consolidated - particularly that of rhubarb, which became the cathartic of choice throughout the Middle East and Europe to the beginning of the twentieth century. ${ }^{13}$ Again, it was largely through the tribute sent by the İl-khāns to their Yuan kinsmen that several West Asian simples were introduced to China, such as the stomachic mastic (the resin of Pistacia lentiscus) and the emetic nux vomica, the seed of the fruit of the strychnine tree. ${ }^{14}$ Compound medicines also travelled east, principally theriac, at this stage of its history a general panacea as well as an antidote for all kinds of poisons. Theriac's popularity may also have contributed to the appearance of opium as a therapeutic drug in Chinese medical literature at this time, since opium has formed one of its key ingredients since Hellenistic times. ${ }^{15}$

A recent addition to our knowledge of Mongol imperial pharmacology has appeared in Buell and Anderson's edition and translation of the Yin-Shan Cheng-Yao, a dietary manual presented to the Yuan emperor in $1330 .{ }^{16}$ According to them, the very existence of this book is evidence of Middle Eastern influence, as it was the Arabs of Baghdad who invented the cookbook, and nothing similar predates the Yin-Shan Cheng-Yao in China. ${ }^{17}$ As this work was composed by the court nutritionist, to use a modern term, much attention is paid to the medical qualities of the recipes, which were clearly of Middle Eastern origin. These recipes included fenugreek seed soup, bearing indications

11 See Unschuld 1977.

${ }^{12}$ For Islamic medicine, see Ullmann 1978, pp. 64-9, for Chinese pulse diagnosis see for example Hsu 2001 and Kan-wen 1983, pp. 358-68. For a comparison between Greek and Chinese pulse-taking see Kuriyama 2002, particularly part 1.

${ }_{13}^{13}$ For an excellent study of this drug, see Foust 1992, esp. pp. 3-17.

${ }_{14}$ Allsen 2001, p. 154.

is Allsen 2001, pp. 54-5. On opium in general, see Tibi 2006.

${ }^{16}$ Buell and Anderson 2000.

17 Buell and Anderson 2000, pp. 78-9. 
such as 'supplements lower primordial energy, orders loin and knee, warms the center, and accords $c b^{\prime} i[q i]^{18}$ that derive completely from the Chinese medical tradition. Although the culture represented in this work is largely Sinicized, there remains a recognisable and substantial underlay of Mongolian culture. This is expressed, for our purposes, by the use of specific foods with their traditional Mongolian medical values in mind. These traditions seem in part to have been preserved in Mongolian folk medicine down to the present day, such as the use of ephedra stems for rheumatism. ${ }^{19}$

On the other hand, despite the overlay of Chinese medical theory and terminology, the Yin-Shan Cheng-Yao gives evidence of Arabic pharmacological knowledge having been absorbed at least by the Mongol imperial court. For example, the names of many spices that appear there derive from Turkish, Persian and Arabic names used in West Asia. ${ }^{20}$ '[W] hat is new in the YSCY are not the spices, foods and medicines themselves, but the uses to which older borrowings are now put in flavor and ingredient combinations that are unmistakably Western and Islamic'. ${ }^{21}$

The Imperial Pharmaceutical Bureau was established in Peking in 1269 by 'Īsā the Interpreter (1227-1308), a Nestorian physician in the service of Khubilai Khān, nearly a decade after the establishment of an Office for Muslim Medicine there, while special Muslim Pharmaceutical Bureaux were established in both capitals (i.e., Peking and Karakorum) in 1292. ${ }^{22}$ Both of these came under the supervision of another bureau, the Office of Broad Grace (Ghuanghui si) in 1322. Their influence is unclear, but presumably existed, as according to the Yuan History, 'the Office of Broad Grace prepared Islamic medicines for the emperor and treated imperial guards as well as the poor without others to depend on in the capital'. ${ }^{23}$ Evidence for such influence in the Yin-Shan Cheng-Yao are the use of specific materia medica for the indications given in Arabic medicine (for example, onions as aphrodisiacs, ${ }^{24}$ and more prosaically, fennel as a powder used as a stomachic $)^{25}$ and the dose forms used, especially those with a sugar base such as syrups. As noted previously,

${ }^{18}$ Buell and Anderson 2000, p. 279.

19 Meserve 2004, p. 98.

${ }^{20}$ Buell and Anderson 2000, pp. 108-16. Examples of such names are badam (Persian for almond), bulba (Arabic for fenugreek), zaifarän (Arabic for saffron) and zhira (Persian for cumin).

${ }^{21}$ Buell and Anderson 2000, p. 117.

${ }^{22}$ Allsen 2001, p. 150.

${ }^{23}$ Shinno 2002, pp. 62-3. I thank John Moffat of the Needham Research Institute, Cambridge, for providing me with a copy of this dissertation.

${ }^{24}$ Buell and Anderson 2000, p. 126.

${ }^{25}$ Buell and Anderson 2000, p. 127. 
syrups were by far the most popular dosage form in the Islamic Middle East. According to Buell and Anderson, ${ }^{26}$ one of the most obviously West Asian features of the medical sections of the Yin-Shan Cheng-Yao is the presence of recipes requiring large quantities of more or less refined crystal sugar: 'Syrups, sharbuts, confits, jams, preserves and other confectionery became preferred ways to administer all kinds of medicinal substances. ${ }^{27}$

Finally, certain recipes seem to have been copied intact from the Arabic tradition, such as the following 'four harmonies puree': ${ }^{28}$

It cures chill pain of the abdomen, and disharmony of spleen and stomach.

White flour (one chin; roast), sesame [seeds] (one chin; roast), fennel (two liang, roast), salt (two liang, roast).

Make all ingredients into a fine powder. Take a little each day on an empty stomach in boiling water.

Another example, which could easily have come from any Arabic pharmacopoeia, is a recipe for pomegranate syrup: 'Pomegranate seeds ( $10 \mathrm{chin}$; take the juice). White sugar (ten chin; refine). Boil ingredients together and make a concentrate'.$^{29}$ And indeed, an identical recipe appears in Minhäj al-dukkän: sharäb al-rummän al-hilw, combining the juice of sweet pomegranates with sugar. ${ }^{30}$ The main differences between the formulary and the cookbook in this case are that the former gives indications-this syrup is good for coughs and pains in the chest-and detailed instructions on how to extract the pomegranate juice, while the latter does neither. A detailed comparison of the recipes of the Yin-Shan Cheng-Yao with those contained in contemporary Arabic cookbooks and formularies, such as the Kanz al-fawä id and Minhäj al-dukkän, would further elucidate the Islamic influence on Chinese foodways, and quite possibly, the other direction as well. This is clearly a desideratum, but is beyond the scope of this article.

Finally, I will discuss the role played by pharmacists in hospitals of the Mamlūk/Mongol period, based on an analysis of the waqf (pious endowment) documents in which the terms of employment are set out. ${ }^{31}$ Not many waqfiyyas from the pre-Ottoman Middle East have survived. I rely here on the

${ }^{26}$ Buell and Anderson 2000, p. 119.

27 Buell and Anderson 2000, p. 123, n. 40.

${ }^{28}$ Buell and Anderson 2000, p. 380.

${ }^{29}$ Buell and Anderson 2000, pp. 338-9.

${ }^{30} M D$, p. 26.

${ }^{31}$ A terminological note of clarification: A waqf is the pious endowment of income from land, rents, shops, etc. for the permanent benefit of Muslims in the form of a hospital, soup kitchen, cemetery upkeep etc., while a waqfiya (Arabic) or waqf-nama (Persian) is the legal document setting out the terms of the waqf. 
published waqfyyas of two of the most famous hospitals of the thirteenth century: the Manșūrī hospital in Cairo and the Rab'-i Rashīini in Tabriz. While it must be taken into account that the instructions appearing in waqfiyya documents reflect the desires of the founder, rather than the actual reality of hospital management, in the absence of any other documentation I regard the waqfiyyas as an indication of ideal practice, describing the way the medical establishment wished to view the relationship between pharmacists and physicians.

The Islamic hospitals have been the subject of much interest in research, ${ }^{32}$ at least in part due to their reputation as the forerunners of modern hospitals. ${ }^{33}$ However, it should be remembered that medieval hospitals were primarily seen as playing a charitable role, insofar as they provided care mainly for the poor and for strangers, who could not rely on their own families. The more usual-perhaps even the more prestigious-place of medical treatment was the home. ${ }^{34}$ As charitable institutions, hospitals were funded through the establishment of awqäf (sing. waqf), inalienable pious endowments for the benefit of the Muslims in general (and in many cases, of the founder's descendants specifically - the establishment of a waqf was a common method of circumventing both Islamic inheritance laws and the Mamlūk practice of confiscating excess wealth). ${ }^{35}$ According to Sayll, "The endowment of the hospital with waqf constituted a sign of a more complete integration with Moslem culture and civilization, and it was also a guarantee of the hospital's longevity'. ${ }^{36}$

The best-known hospital of the Mamlūk period, and that for which the most complete documentation survives, is without a doubt the Manșūri hospital, founded by the sultān Qalāwūn in 1285 as part of a tomb-school-hospital complex in the heart of Cairo. ${ }^{37}$ According to the terms of the waqfiyya, it was meant to provide medical treatment to all Muslims, male or female, Cairenes or foreigners, who needed it. ${ }^{38}$ According to Ibn Abi Ușaybi a's (d. 1290) contemporary description, the hospital was divided into two wings, one for men and one for women. Each wing was further divided into several halls: for

${ }^{32}$ See, for example, Hamarneh 1962; Dols 1987.

${ }_{33}$ On this see Sayilı 1980; Nowsheravi 1983; Pormann 2003.

${ }^{34}$ Dols 1987, p. 370.

${ }^{35}$ For the hospital as a waqf, see Lev 2003.

${ }^{36}$ Sayilı 1980, p. 283.

${ }^{37}$ For a physical description of the hospital and its location, see al-Maqrīiei 1852, pp. 405-6. For a discussion of Qalāwūn's patronage of medicine, see Northrup 2001, pp. 124-30.

${ }^{38}$ Amin 1976, pp. 358-9, 11. 215-26. For a complete discussion of this hospital as a charitable institution, see Sabra 2000, pp. 69-80. 
internal medicine, for opthalmology and for surgery, corresponding to the three kinds of physician mentioned in the waqfiyya. The hall for internal medicine was subdivided into chambers for patients suffering from fevers (almahmümin), depression or cold fever (al-mabrüdinn), madness (al-mamrürīn) and diarrhoea (ishäl). ${ }^{39}$ Each division was staffed by one to three physicians, the most senior of whom bore the title of $r^{\prime}{ }^{\prime} i{ }^{4}{ }^{40}$

The inspector (näzir) of the hospital was a highly important person. He was ultimately responsible for making sure that the ingredients (especially sugar and fruits) for a multitude of different preparations were bought at the right time, and were correctly prepared and stored in sufficient quantity to provide for the needs of all patients. ${ }^{41}$ This required the establishment of a permanent, well-stocked storeroom, so that any patient could receive the drugs he needed. This in turn made the post of pharmacist imperative: the waqfiyy stipulates that the inspector should appoint a trusty and religious man to be in charge of the medicines and herbs, who would be responsible for preparing medicines according to the physicians' orders. ${ }^{42}$ These medicines included theriac, the well-known panacea prepared from the flesh of vipers, among other ingredients. However, at least when the sultan Qāyitbāy asked to see the procedure of preparing theriac, it was performed by the physicians, helped by a snakecharmer ( hawwi) , rather than by pharmacists. ${ }^{43}$

The list of functionaries responsible for the patients' welfare (man yaqüm bi-masälih al-mardā) includes physicians, oculists, surgeons, cooks for syrup, rhubarb and foodstuffs (tabbäkhi al-sharäb wa-'l-räwand wa-'l-tu'üm) and preparers of electuaries, eye-powders, medicines and purgatives (șaniti alma'äjin wa-'l-akhäl wa-'l-adwiya wa-'l-mushilät). ${ }^{44} \mathrm{~A}$ further list of the medicaments to be provided in the hospital specifies food and drink together with eye-salves, eye-powders, electuaries, poultices, oils, syrups and simple and compound medicines. ${ }^{45}$

The näzir was not responsible for the medical needs of hospital inmates only. He was also required to send various medicines to the poor of Cairo who

${ }^{39}$ As quoted in Amin 1976, p. 303.

${ }^{40}$ Ibid.

${ }^{41}$ Amin 1976, pp. 363-4, 1l. 257-62.

${ }^{42}$ Amin 1976, p. 364, 11. 267-9.

${ }^{43}$ See Ibn Iyās 1931-1975, p. 358. For details of the interest of later sultans in the hospital pharmacy, see Hazan 2004, pp. 182-4. I thank Professor Yaacov Lev for providing me with a photocopy of these pages.

${ }^{44}$ Amin 1976, p. 360, 11. 233-5.

${ }^{45}$ Amin 1976, p. 361, II. 236-7: al-aț ima wa-'l-ashriba wa-'l-akhäl wa-'l-shiyäfät wa-'lma'ajin wa-'l-marähim wa-'l-adhän wa-'l-sharibät wa-'l-adwiya al-murakkaba wa-'l-mufrada. Cf. also p. 363, ll. 258-9. 
remained in their homes, and even to make arrangements for the proper laying-out and burial if such a person died at home. ${ }^{46} \mathrm{It}$ is not clear to what extent this role of public health officer was carried out in reality. ${ }^{47}$

From the terms of the waqfiyya, it is clear that the provision of medicine was the most important function of the Manșuri hospital. If the income of the waqf should fall short of enabling the hospital to provide all the services it was intended to, the priority was to continue dispensing medicaments. ${ }^{48}$ It is equally clear that the pharmacist played a very subordinate role in this process. The physicians were responsible for prescribing medicines; the näzir was responsible for providing the raw materials. The pharmacist was a mere technician, complying with the directives of others and compounding medicines. He did not even have the responsibility of providing them to the patients himself; this was the function of yet another person. ${ }^{49}$

To turn now to the Mongol example. One of the major figures of the İlkhānid court was the vizier and historian Rashìd al-Dīn ${ }^{50}$ Faḍlallāh b. 'Imād al-Dawla (c. 1247-1318), the son of a Jewish apothecary of Hamadān. $\mathrm{He}$ rose to high office first under Ghazan (r. 1294-1304) and then under Öljeitü (r. 1304-16), although never as sole chief minister. He met his death at the hands of Öljeitü's successor, Abū Sa'ìd, when he was accused of having poisoned his previous master. After his execution (in front of his son Ibrähīm, according to al-Safadi), his head was taken to Tabriz and the rest of his body was dismembered, a part being sent to every province. ${ }^{51}$

Apart from being one of the most active cultural brokers of the early Mongol period in Iran, his most enduring achievement was the composition of the Jämi" al-tawärikh, considered the first true 'world history'. ${ }^{52}$ To his contemporaries, however, his fame was as a physician and the endower of the magnificent Rab'-i Rashìii:

Rashid, it will be recalled, first entered Mongolian service as a cook/dietician and doctor. He was so identified with this profession that to his contemporaries he was Rashìd the Physician (tabib). He used his wealth and political influence to

${ }_{46}$ Amin 1976, p. 367, 11. 291-4.

47 The discussion of developments after the foundation of the hospital in al-Hajji 1992, pp. 232-44, deals mainly with personnel changes, and makes no reference to this aspect of the näzir's post.

${ }^{48}$ Amin 1976, p. 368, 1l. 301-2.

49 Amin 1976, p. 305.

${ }^{50}$ In Mamlük sources, the laqab Rashid al-Din ('rightly guided of the religion', i.e. in Islam) is usually replaced by Rashid al-Dawla ('rightly guided of the dynasty'). This reflects his nonMuslim origins. See Amitai-Preiss 1996, p. 26.

51 al-Șafadi 1990, vol. 50 (3 parts), part 2, p. 337.

52 See Jahn 1967; Boyle 1971. 
further, in various ways, his chosen profession. Most spectacularly, he built in Ghazan's time the Rab'-i Rashidi, a suburb of Tabriz, that became a center for scholars of the most diverse interests and origins, which made the Il-qan capital one of the leading cultural clearing houses of medieval Eurasia. His house included a House of Healing that was both a hospital and a medical training facility. ${ }^{53}$

In her magisterial study of the waqf-näma (endowment document) of Rashid al-Din Tabib's charitable foundation in Tabriz, Birgit Hoffman points out that the word 'hospital'-bimäristän-does not appear in that document. There seems to have been no specific structure used as a hospital: patients were either residents of the quarter who stayed in their own homes, or else visitors, who resided in the riwãq al-murattabin. Rather, the phrases där al-shifä́ (house of healing), därükhäna or bayt al-adwiya (both: house of medicines) are used to indicate places where foods and medicines for the ill were prepared. ${ }^{54}$

The medical personnel of the Rab -i Rashidi indicates a medical establishment far smaller than that of the Mansūrì Hospital. It comprised a physician, who was also required to teach medicine (tabib, mudarris-i ilm- $i$ tibb), two medical students (mutallimān), an oculist (kaḥhäl), a surgeon (jarräb) these two posts may have been held by one person-an apothecary (sharäbdär) and an overseer of the apothecary's storeroom (khazin). In addition, the staff included a repetitor ( $\left.m u^{\prime} i d\right)$, two servants (khädim or qayyim), a cook (matbakhī), a housekeeper ( farräsh), a water-carrier (saqqā) and a doorkeeper $($ bawwäb). A comparison of the salaries paid to these immediately reveals a vast gap between the physician (330 dinārs a year) on the one hand, and the pharmacist (40 dinārs a year) on the other, with the surgeon/oculist (100 dīnārs a year) in the middle. This discrepancy also indicates a gap in prestige and status, especially when it is noted that the pharmacist's remuneration of 40 dinārs per year and 4 mann (c. $3.2 \mathrm{~kg}$.) of bread per day is only slightly higher than that of the support staff, all of whom received 30 dinārs per year and 2 mann (c. $1.6 \mathrm{~kg}$.) of bread per day. ${ }^{55}$ Indeed, the pharmacist is not dignified with the title of 'attär or saydali, but rather is referred to as the person 'responsible for syrups' (sharäbdār).

According to the terms of the waqf-näma, the sharäbdär of the därükhäna was required to be pious and trustworthy, avoiding alcoholic drinks. He was in charge of preparing medicines (adwiya) and syrups (ashriba) for the patients, and other electuaries (máajin) and compound medicines in general

53 Allsen 2001, pp. 143-4.

54 Hoffmann 2000, p. 129. A condensed study of the same subject in English is Hoffmann 1997.

55 Hoffmann 2000, pp. 235, 274-5. 
(murakkabät), following the physician's instructions. ${ }^{56}$ The overseer of the storeroom (khäzin-i därükhäna) was in charge of its key, and brought the medicaments required by the physician to the pharmacist. As may be imagined from this, he was answerable not to the sharabdar, but to the physician. ${ }^{57}$

On Mondays and Thursdays, specific medicaments were distributed to the residents, servants and sojourners of the Rab'-i Rashidi. These ranged from polypharmaceutical panaceas going back to Hellenistic times, like theriac (tiryäq-i färüq and tiryäq-i arba'a), mithradaticum (mițrüdițüs) ${ }^{58}$ and philonium romanun ( falüniyā-yi rümì) to simple oils (adhän), such as oil of violets (banafsha), of jasmine (yäsamin) and of bitter almonds (bädäm-i talkh). The physician would sit at the door of the därükhäna and write out a prescription. The overseer of the storeroom would bring the materia medica required to the sharäbdar, who would prepare the medicine. When anyone was ill and stayed at home, food (usually soup), drinks and medicines were prepared by the sharäbdär and delivered to the home. ${ }^{59}$

Judging from the instructions set out in the waqf-näma, as well as their relative salaries, it seems that in the Rab'-i Rashidi, the pharmacist was clearly subordinate to the physician. His role was reduced to carrying out the instructions of the physician, who was expected to be fully conversant with both the theory and practice of all aspects of medicine, including pharmacology. This, indeed, is the traditional physician-defined position of the apothecary.

Did the Islamic hospital, as an institution, have any influence on the development of medical practice in China? Many of the medical men, Muslims and Nestorians alike, who moved from Iran further east must have had experience in hospitals. The very arrival of these men, in the wake of the Mongol conquest and the establishment of the Yuan dynasty, helped shape the evolution of medicine in China and particularly the social standing of physicians in the course of the thirteenth century, with Confucian literati who would previously have scorned this career track, becoming doctors in increasing numbers. ${ }^{60} \mathrm{An}$ aspect of this change is the development of medical schools in the Temples of the Three Progenitors in Yuan China. Medical school instructors and their students met twice a month in these temples to discuss medical theory and practice and to perform rituals celebrating the Three Progenitors,

\footnotetext{
56 Hoffmann 2000 , p. 314.

57 Hoffmann 2000 , p. 315.

${ }^{58}$ On the transmission of Hellenistic polypharmacy, particularly theriacs, see Totelin 2004.

59 Hoffmann 2000, pp. 271-3.

${ }^{60}$ Allsen 2001, pp. 157-8; Shinno 2002, p. 132.
} 
seen as role-models particularly appropriate to physicians. The teaching of medicine in the temples raised medicine to the status of learning (xue), knowledge that Confucian gentlemen might honourably pursue. ${ }^{61}$

I am tempted to see a reflection of the mosque-hospital-Quran school complexes funded together through the mechanism of waqf in this conflation of temple and medical school. Of course, there are many differences between the two systems, not the least being that the Chinese model appears to concentrate on theory, while the Islamic hospital, although theory was what was formally taught, certainly had a very practical side to it. However, the idea of a religious component to the institution where medicine was taught appears to be an innovation in the Chinese context. Again, this is a topic requiring further research.

What changes, then, if any, did the coming of the Mongol Empire make to the practice of Islamic medicine? 'Islamic' in this context has no religious connotation, but rather a geographical one, referring to lands under Muslim rule or conquered by the Mongols from Muslim rulers. The evidence of Minhäj al-dukkan suggests that very little changed. This work lies firmly within the confines of the Arabic pharmacological tradition which is basically Galenic, and became enriched by Central Asian, Indian and Far Eastern materia medica centuries earlier. Minhaj al-dukkan quotes many earlier authorities by name, ranging from classical authorities through major Muslim figures and down to his own teachers and contemporaries. The fact that this book became the manual for pharmacists, still in use in Cairo in the $1960 \mathrm{~s},{ }^{62}$ surviving in over 30 manuscripts and printed at least nine times since 1870, most recently in 1992 (in Beirut) and in 2003 (in Cairo), shows how little the practice of pharmacy changed over time.

This is further borne out by the comparison of the waqfyyas of the two hospitals, one on either side of the border. Given both texts with all identifying markers removed, one would be hard put to say which derived from the Mamlük and which from the Mongol realm. Connections between the Mamlük and Mongol realms at the time of the Mongol Empire brought about significant transfers of knowledge in medical practice. The implications which these have had on Chinese medicine are yet to be fully studied.

\footnotetext{
61 Shinno 2002, pp. 202-3.
}

${ }^{62}$ Levey 1973, p. 98. 


\section{References}

Allsen T. 2001, Culture and Conquest in Mongol Eurasia, Cambridge: Cambridge University Press.

Amin Muhammad M. 1976, Wathä' iq waqf al-sulțän qalä'ün 'alä' l-bimäristän al-manșürì, Cairo: Dār al-Kutub al-Miṣriyya.

Amitai-Preiss R. 1996, 'New Material from the Mamluk Sources for the Biography of Rashid al-Din', in J. Raby and T. Fitzherbert (eds), The Court of the Il-khans 1290-1340, Oxford: Oxford University Press, 23-37.

al-Antaki Dāwūd 1998, Tadhkirat ùlì al-albäb, vol. 1, Beirut: Dār al-Kutub al-'Ilmiyya.

al-'Aț̣ār Abū al-Munā al-Kūhīn 1992, Minhäj al-dukkān, ed. Ḥ. al-'Āṣī, Beirut, Dār al-Manāhil.

Boyle J. A. 1971, 'Rashid al-Din: The First World Historian', Iran, 9: 19-26.

Buell P. and E. Anderson 2000, A Soup for the Qan, London: Kegan Paul.

Dols M. W. 1987, 'The Origins of the Islamic Hospital: Myths and Reality', Bulletin of the History of Medicine, 61: 367-90.

Foust C. 1992, Rhubarb: The Wondrous Drug, Princeton, NJ: Princeton University Press.

al-Ḥajji H. N. 1992, 'al-Bīmāristān al-manșūrī mundh ta'sisihā wa-ḥattā nihāyat al-qarn al-thāmin al-hijrī / al-rābi' 'ashar al-milādì '(The Manșūrī hospital from its foundation until the end of the eighth century AH / fourteenth century AD), in H.N. al-Hajji, Suwar min al-hadàra al-arabiyya al-islämiyya fi saltanat al-mamälìk, Kuwait: Där al-Qalam, 1992, 232-44.

Hamarneh S. K. 1962, 'Development of Hospitals in Islam', Journal of the History of Medicine and Allied Sciences, 17: 366-84.

Hazan U. 2004, 'Medical, Administrative and Financial Aspects of Hospitals in Medieval Islam, 8th-15th Centuries', [in Hebrew: Heibetim refu'iyyim, minhaliyyim ve-kalkaliyyim be-vatei holim ba-islam shel yemei ha-beinayim, me'ot 8-15] unpublished $\mathrm{PhD}$ dissertation, Bar-Ilan University.

Hoffmann B. 1997, 'The Gates of Piety and Charity: Rašid al-dinn Faḍl Allāh as Founder of Pious Endowments', in D. Aigle (ed.), L'Iran face à la domination mongole, Tehran: Institut français de recherche en Iran, 189-201.

2000, Waqf im mongolischen Iran: Rašiduddins Sorge um Nachruhm und Seelenheil, Stuttgart: Franz Steiner Verlag.

Hsu E. 2001, 'Pulse diagnosis in the Western Han: how mai and qi determine bing', in E.Hsu (ed.) Innovation in Chinese Medicine, Cambridge: Cambridge University Press, 51-91.

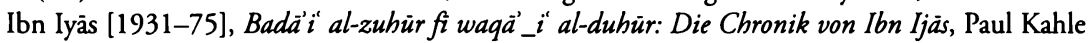
and Mohamed Mustafa, (eds), Wiesbaden: Franz Steiner Verlag.

Ibn Jumay' al-Isrāīili, Hibbatallāh b. Zayn [n.d.], al-Irshäd li-masălih al-anfus wa-'l-ajsäd. Bethesda, MD: US National Library of Medicine MS A22.

Ibn Sinā 1999, al-Qänün fí 'l-țibb, Beirut, Dār al-Kutub al-'Ilmiyya.

Jahn K. 1967, 'Rashìd al-Dīn as World Historian', Yádnáme-ye Jan Rypka, Collection of articles on Persian and Tajik literature, Prague: Akedemia: Publishing House of the Czechoslovak Academy of Sciences, 79-87.

Kan-wen Ma 1983, 'Diagnosis by Pulse Feeling in Chinese Traditional Medicine', Ancient Chi$n$ a's Technology and Science, Peking, Foreign Language Press, 358-68.

Kuriyama S. 2002, The Expressiveness of the Body: and the Divergence of Greek and Chinese Medicine. New York: Zone Books.

Lev Y. 2003, 'Politics, Education and Medicine in Eleventh-Century Samarkand. A Waqf Study', Wiener Zeitschrift für die Kunde des Morgenlandes, 93: 119-45.

Levey M. 1973, Early Arabic Pharmacology, Leiden: Brill.

Lo V. and P. Barrett 2005, 'Cooking up Fine Remedies: On the Culinary Aesthetic in a Sixteenth-Century Chinese Materia Medica', Medical History, 49: 395-422. 
al-Majūsī, 'Alī ibn al-'Abbās 1294/1877, Kitäb al-Malaki, Cairo: al-Maṭba'a al-Kubrā.

al-Maqrizī, Taqi al-Dīn Abū 'l-Abbās Aḥmad b. 'Alī 1270/1852, Kitäb al-mawä’ iz wa-'l-ítibär fí dhikr al-khitat wa-'l-äthär, Bülāq, 2 vols.

Marín M. and D. Waines (eds) 1993, Kanz al-fawä̉id fi tanwï al-mawäid (Medieval Arabl Islamic Culinary Art), Beirut and Stuttgart: Franz Steiner Verlag.

Meserve R. I. 2004, 'A Mongolian Medicinal Plant List', Journal de la Société Finno-Ougrienne, 90: 67-100.

Northrup L. S. 2001, 'Qalāwūn's Patronage of the Medical Sciences in Thirteenth-Century Egypt', Mamlük Studies Review, 5: 119-40.

Nowsheravi A. R. 1983, 'Muslim Hospitals in the Medieval Period', Islamic Studies, 22: 51-62.

Pormann P. 2003, 'Theory and Practice in the Early Hospitals in Baghdad-al-Kaškarī on Rabies and Melancholy', Zeitschrift für Geschichte der Arabisch-Islamischen Wissenschaften, 15: 197-248.

al-Rāzī Abū Bakr [1955], Kitäb al-häwĩ fí 'l-țibb, Hyderabad: Dā'irat al-Ma'ārif al-'Uthmāniyya.

Sabra A. A. 2000, Poverty and Charity in Medieval Islam: Mamluk Egypt, 1250-1517, Cambridge: Cambridge University Press.

al-Șafadī Khalīl ibn Aybak 1990, A'yän al-nașr wa-a'wän al-'așr (The important persons of the age), Fuat Sezgin (ed.), Frankfurt: Institute for the History of Arabic-Islamic Science, Series C: Facsimile editions, vol. 50 (3 parts).

Sayil A. 1980, 'The Emergence of the Prototype of the Modern Hospital in Medieval Islam', Türk Tarih Kurumu Basimevi Belleten, 44: 279-86.

Shinno R. 2002, 'Promoting Medicine in the Yuan Dynasty (1206-1368): An Aspect of Mongol Rule in China', unpublished $\mathrm{PhD}$ dissertation, Stanford University.

Tibi S. 2006, The Medicinal Use of Opium in Ninth-Century Baghdad, Leiden: Brill.

Totelin L. M. V. 2004, 'Mithradates' Antidote-A Pharmaceutical Ghost?', Early Science and Medicine, 9: 1-19.

Ullmann M. 1978, Islamic Medicine, Edinburgh: Edinburgh University Press.

Unschuld U. 1997, 'Traditional Chinese Pharmacology: An Analysis of its Development in the Thirteenth Century', Isis, 68: 224-8.

Waines D. 1995, 'Medicinal Nutriments as Home Remedies: A Case of Convergence between the Medieval Islamic Culinary and Medical Traditions', in Concepcíon Vasquez de Benito et al. (eds), Actas XVI Congreso UEAI, Salamanca, Agencia Española de Cooperación Internacional-Consejo Superior de Investigaciones Científicas-Union européenned'arabisants et d'islamisants, 551-8. 